\title{
Frequency and correlation of lip prints, fingerprints and ABO blood groups in population of Sriganganagar District, Rajasthan
}

\author{
Harpreet Sandhu, Pradhuman Verma, Sarfaraz Padda, Seetharamaiha Sunder Raj
}

Department of Oral Medicine \& Radiology, Surendera Dental College \& Research Institute Sriganganagar (Rajasthan), India

Correspondence: pradhuman_verma@rediffmail.com Tel.: + 919660127525

Fax.: + 911542440102

Received: 23 Mart 2017

Accepted: 30 November 2017

Key words: Cheiloscopy - Dermatographics - Forensic - Gender - Personnel identification.

\section{Introduction}

The positive identification of the living or deceased using distinct traits is a cornerstone of forensic science. According to Locard's exchange principle, when two objects come into contact, there is always a transfer of material from one to the other. Traces from the scene may be carried away by a
Objective. To investigate the frequency and uniqueness of different lip print patterns, fingerprint patterns in relation to gender and $\mathrm{ABO}$ $\mathrm{Rh}$ blood groups among a semi-urban population of Sriganganagar, Rajasthan. Materials and methods. The study was conducted on 1200 healthy volunteers aged 18-30 years. The cheiloscopic and dermatographic data of each subject were obtained and were analysed according to the Suzuki and Tsuchihashi and Henry systems of classification, respectively. Two forensic experts analyzed the patterns independently. The ABO Rh blood group was also recorded for each subject. The Chi square statistical analysis was done and tests were considered significant when $p$ value $<0.001$ and Cohen kappa test was applied to analyze inter-observer reliability. Results. The B+blood group was noted as most common in both genders while least common were $\mathrm{A}$ - among males and $\mathrm{AB}$ - in females. Type II lip pattern was most predominant while the least common was Type I' in males and Type I' and Type V in females. The UL fingerprint pattern was the most common, while RL was least noted in both genders. All the fingerprint patterns showed correlation with different lip print patterns. A correlation was found between different blood groups and lip print patterns except Type I (vertical) lip pattern. A positive correlation was observed between all the blood groups and fingerprint patterns, except for RL pattern. Conclusion. There is an association between lip print patterns, fingerprint patterns and $\mathrm{ABO}$ blood groups in both the genders. Thus, correlating the uniqueness of these physical evidences sometimes helps the forensic team members in accurate personal identification or it can at least narrow the search for an individual where there are no possible data referring to the identity of the subject. person and at the same time may be left at the scene (1). The fingerprints, lip prints and blood remains are evidence left at the crime scene which can be utilized for forensic identification purpose based on the same principle. The use of these three physical forms of evidence is of paramount importance, since undertaking personal identification 
by other means such as DNA analysis is a sensitive and costly technique and therefore difficult to use for each and every case (2). Moreover, correlating this physical evidence at the crime scene altogether, rather than individual pieces of evidence alon, sometimes helps the forensic team members in accurate identification. Also, they can be used to substantiate facts in crimes where there is very little evidence, especially in regional mass disasters, accidents or crimes.

Lips surround the oral orifice and are covered by mucosa and partly by skin. When identification is concerned, the mucosal area is important, which is called Klein's zone, covered with wrinkles and grooves on the labial mucosa, forming characteristic patterns called lip prints (3). Suzuki and Tsuchihashi (4) established that the arrangement of lines on the red part of the human lip is individual and unique. The lip prints are identifiable as early as from the sixth week of intrauterine life. Mc Donell (5) reported in 1972 that two identical twins, who seem to be indistinguishable by any other means, can be distinguished by their lip prints. The lip prints on a drinking glass, clothing or cigarette butt found at crime scenes may be a link to a suspect and can be obtained for up to 30 days after being produced $(6,7)$. The lipstick-cellophane tape method used in lifting lip prints was first described by Bindalet al. (8). These latent and invisible lip patterns can be detected using aluminium powder, Sudan III dye, silver nitrate powder, plumb carbonate powder, fat black aniline dye, cobalt oxide, Indigo blue dye or magnet powder. The latent lip prints can be better developed using materials that are more sensitive to fatty acids. Lysochromal dyes contain an ingredient that dissolves in contact with fat and another that stains and, hence, have the ability to stain fatty acids while developing latent lip prints (9).

Moreover, in the case of a deceased person, the lip prints have to be obtained within
24 hours to prevent them from undergoing post-mortem changes. In 1967 Santos (10) classified lip grooves into four types (straight line, curved line, angled line and sine shaped line). In 1970 Suzuki and Tsuchihashi (4) devised a new classification of lip grooves as: Type I: A clear groove running vertically across the lip; Type I': Partial length groove of type I; Type II: A branched groove; Type III: An intersected groove; Type IV: A reticular pattern; Type V: Undetermined.

Dermatoglyphics is defined as the scientific study of epidermal ridges and their configuration on the volar aspect of the palmar and planter regions (11). Herschel (12) used fingerprints for personal identification in India. The palmar surfaces of hands have friction ridges, known as papillary or epidermal ridges. The establishment of the epidermal ridges takes place at from $10^{\text {th }}$ to $16^{\text {th }}$ weeks of development. As the fingerprint patterns are encoded on the interface between the dermis, the pattern cannot be destroyed by superficial skin injuries. Henry's classification is the most accepted and commonly used system, that allows for logical categorization of ten-print fingerprint records into primary groupings based on the physiological characteristics of the fingerprint pattern types. The three basic patterns of fingerprint ridges according to Henry's system (13) of classification are: a) Arch (plain and tented): An arch is a pattern where the ridges enter from one side of the finger, rise in the centre forming an arc, then exit from the other side of the finger; b) Loop (radial and ulnar, double or pocket): A loop is a pattern where the ridge enters from one side of a finger, forms a curve and tends to exit from the same side they entered c) Whorl (plain): A whorl pattern ridge forms circularly around a central point on the finger.

The blood group system was discovered in 1901 by Karl Landsteiner (14). The ABO' system is further classified as $A, B, A B, O$ blood group types according to the corre- 
sponding antigen in the plasma, while the Rhesus system is classified into $\mathrm{Rh}+$ and $\mathrm{Rh}-$ according to the presence or absence of $\mathrm{D}$ antigen.

Although the studies correlating and comparing all these three variables are minimal, in a few studies $(15,16)$ significant correlations were found between them. Nandan et al. (17) also revealed in his study the weaker but still clear significance of lip prints and fingerprints in gender identification. Moreover, the sample size in previous studies $(6,18)$ was quite small (ranging from 54 to 208). Taking this shortcoming into consideration, this study was designed to be conducted on a much larger sample size that could give us a better correlation in between these three variables.

Hence, with this background, the present study was conducted to investigate the prevalence and correlation of lip print patterns, fingerprint ridges patterns and $\mathrm{ABO}$ blood groups among both genders in the population of Sriganganagar District, Rajasthan.

\section{Material and methods}

The present study was conducted at the Department of Oral Medicine and Radiology, Surendera Dental College and Research In- stitute, Sriganganagar, District Rajasthan, on 1200 randomly selected healthy volunteer subjects of both sexes, between the ages of 18 to 30 years. The study sample was considered arbitrarily. The inclusion criteria of the study consisted of: 1 . Healthy males and females with no systemic, metabolic, dermatological or endocrinal disease. 2. Individuals who were non-syndromic. 3. Individuals born and brought up in Sriganganagar (North-western India) and of Indo-Aryan ethnic origin. The exclusion criteria consisted of: 1 . Individuals with missing anterior teeth. 2. Individuals with permanent scars on fingers or lips caused by injuries, inflammation or surgery. 3. Individuals with worn fingerprints, extra, webbed or bandaged fingers. 4. Bacterial, viral or fungal infections affecting lips and hands.

\section{Method of collection of lip prints}

The lips of the subject were cleaned and allowed to dry for 1 minute and a red lipstick was applied uniformly to the lips. After 2 minutes, the glued portion of the cellophane tape was evenly placed and stuck to the closed lips in normal resting position, covering the entire portion of both lips, without any movement. The strip of cellophane was

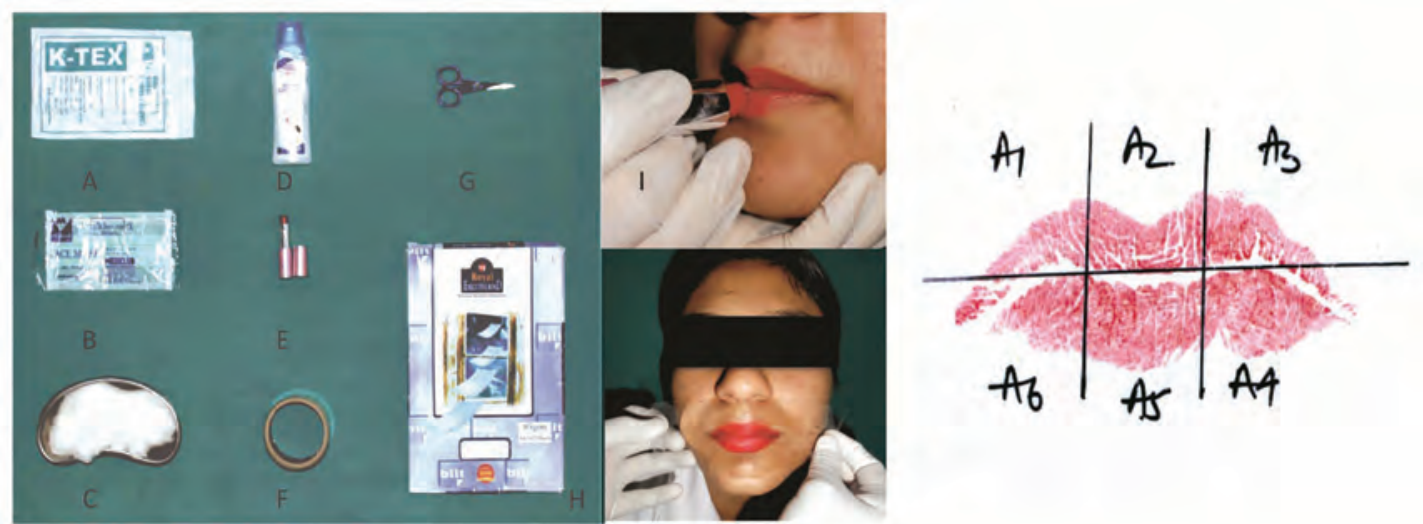

Figure 1 The equipment and procedure used for recording Lip Prints: (A) Gloves; (B) Mouth mask; (C) Kidney tray); (D) Cleansing milk; (E) Red lipstick; (F) Cellophane tape; (G) Scissor; (H) Bond paper; (I) Procedure used for taking lip prints. 
removed and was properly stuck to the white bond paper (A4) without any wrinkles for a permanent record. Each lip print was divided into six areas starting from the upper right area to the lower right area (A1-A6). The lip prints were analysed following $\mathrm{Su}$ zuki and Tsuchihashi's (4) classification using a magnifying glass, by two Forensic experts independently, and the type of pattern which was repeated the maximum number of times, was considered as described by $\mathrm{Ra}$ jendran Sivapathasundram (19) (Figure 1).

\section{Method of collection of fingerprints}

For the fingerprints, the right hand of the subjects was considered as this is the side that most government agencies legally collect. The impressions of all five fingers were taken by asking the subjects to roll the tip of their right hand fingers across the surface of the stamp pad (Camlin of size $157 \times 96 \mathrm{~mm}$ ) and then to transfer the fingerprint impressions onto A4-size white bond paper. The fingerprint patterns were analyzed following Henry's classification (13) using a magnifying glass by the same two Forensic experts independently (Figure 2).

\section{Method of determining ABO blood group}

The blood group of the subjects was identified by placing a drop of blood on a slide and treating it with anti- $\mathrm{A}$, anti-B and then anti-Rh sera. The positive agglutination of the blood upon treatment with anti-A was considered as blood group A, a positive reaction with anti-B was considered as blood group $\mathrm{B}$, if no agglutination was produced it was blood group $\mathrm{O}$, and if agglutination was seen with both antisera, then blood group $\mathrm{AB}$ was considered. Similarly, a positive agglutination reaction with $\mathrm{Rh}$ antigen was considered $\mathrm{Rh}+$, or otherwise $\mathrm{Rh}-(20)$.

\section{Statistical analysis}

The results thus obtained from lip prints, fingerprints and $\mathrm{ABO}$ blood group samples were tabulated and analysed using SPSS 18.0 (Microsoft Corporation Inc., Chicago, IL, USA) statistical software. The Chi-square statistical analysis was done and tests were considered significant at $p$ value $<0.001$ and the Cohen kappa test was applied to analyse inter-observer reliability.
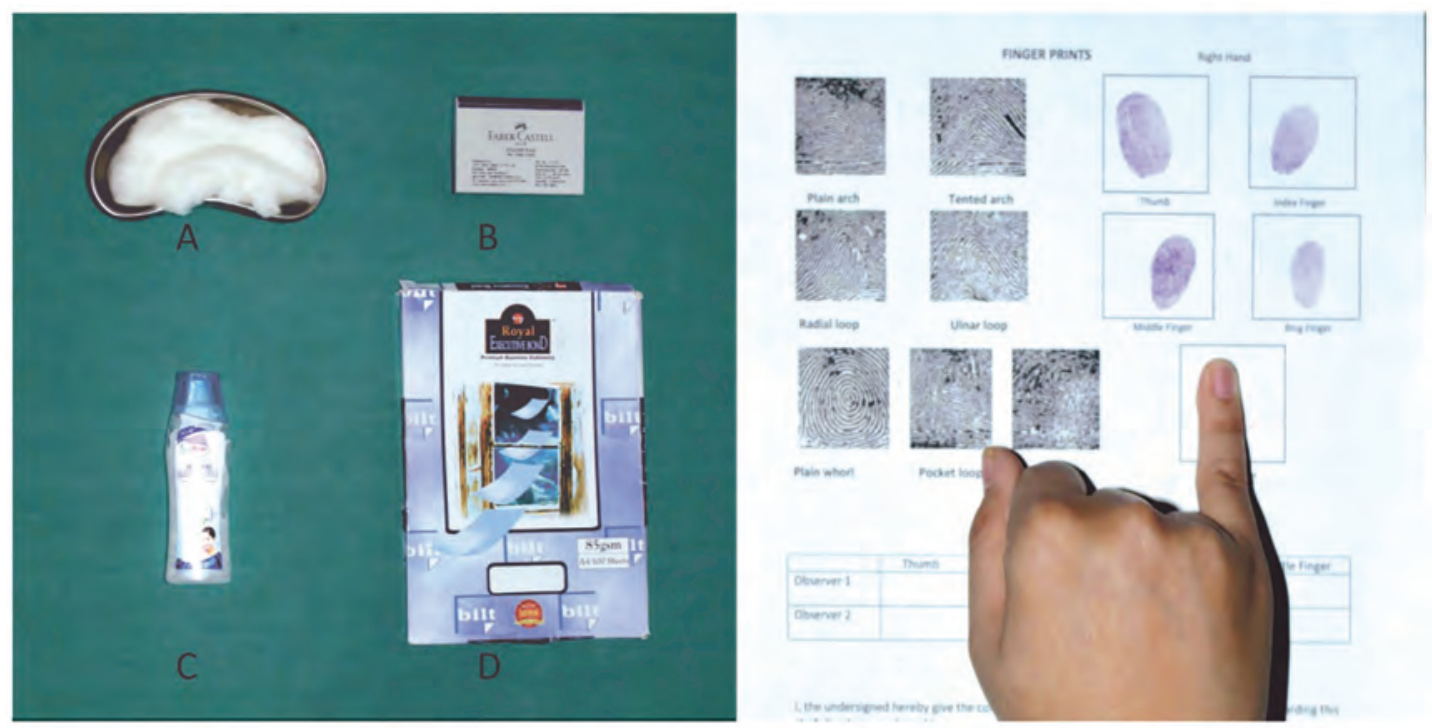

Figure 2 The equipment and procedure used for recording Finger Prints: (A) Kidney tray, cotton; (B) Blue stamp pad; (C) Cleansing milk; (D) Bond paper; (E) procedure used for taking fingerprints. 


\section{Results}

Out of the total sample of 1200 randomly selected subjects aged between 18-30 years, $540(45 \%)$ were males and 660 (55\%) were females, with an overall median age of 20 years. The results of the two observers (observer 01 and observer 02 ) were analysed statistically for lip print and fingerprint patterns, to check inter-observer reliability, using the Cohen kappa test. Since the kappa (k) coefficient value was $>0.8$, which indicated good inter-observer agreement, the interobserver bias was found to be nil (Table 1 and 2) so, for further statistical analysis the results of observer 1 were considered.
Both genders showed the Type II lip pattern to be most predominant while the least common was Type I' in males and Type I' and $\mathrm{V}$ in females (Table1). The ulnar loop (UL) fingerprint pattern was the most predominantly noted in both genders while the radial loop (RL) was least noted in both genders (Table 2). Among the total of 1200 individuals the $\mathrm{B}+$ blood group was noted to be most common in both the genders, while the least common blood group was A- in males and $\mathrm{AB}-$ in females. The distribution of blood groups by gender was not statistically significant (Table 3 ).

Table 1 The prevalence of lip print patterns in both the genders

\begin{tabular}{lllllll}
\hline \multirow{2}{*}{ Types of lip print } & Male & \multicolumn{5}{c}{ Total } \\
\cline { 2 - 7 } & O-1 $(n)$ & O-2 $(n)$ & O-1 $(n)$ & O-2 $(n)$ & O-1 $(n)$ & O-2 $(n)$ \\
\hline I & 46 & 47 & 52 & 49 & 98 & 96 \\
I' & 5 & 4 & 3 & 3 & 8 & 7 \\
II & 278 & 278 & 317 & 317 & 595 & 595 \\
III & 127 & 128 & 178 & 182 & 305 & 310 \\
IV & 73 & 72 & 107 & 105 & 180 & 177 \\
V & 11 & 11 & 3 & 4 & 14 & 15 \\
\hline Total & 540 & 540 & 660 & 660 & 1200 & 1200 \\
\hline Kappa value & 0.81 & & 0.82 & & 0.84 & \\
\hline
\end{tabular}

Type I=A clear groove running vertically across the lip; Type I'=Partial length groove of type I; Type II=A branched groove; Type III=An intersected groove; Type IV=A reticular pattern; Type V= Undetermined; O-1=Observer 01; O-2=Observer 02.

Table 2 The prevalence of fingerprint patterns in both the genders

\begin{tabular}{lllllll}
\hline \multirow{2}{*}{ Types of finger print } & Male & \multicolumn{5}{c}{ Total } \\
\cline { 2 - 7 } & O-1 $(\mathrm{n})$ & O-2 $(\mathrm{n})$ & $\mathrm{O}-1(\mathrm{n})$ & $\mathrm{O}-2(\mathrm{n})$ & O- $(\mathrm{n})$ & O-2 $(\mathrm{n})$ \\
\hline DL & 6 & 6 & 8 & 8 & 14 & 14 \\
$\mathrm{PL}$ & 28 & 28 & 24 & 23 & 52 & 51 \\
$\mathrm{PA}$ & 11 & 11 & 11 & 10 & 22 & 21 \\
$\mathrm{PW}$ & 203 & 204 & 136 & 134 & 339 & 338 \\
$\mathrm{RL}$ & - & 1 & 1 & 1 & 1 & 2 \\
TA & 13 & 13 & 6 & 7 & 19 & 20 \\
UL & 279 & 277 & 474 & 477 & 753 & 754 \\
\hline Total & 540 & 540 & 660 & 660 & 1200 & 1200 \\
\hline Kappa value & 0.64 & & 0.83 & & 0.80 & \\
\hline
\end{tabular}

$\mathrm{DL}=$ Double loop; $\mathrm{PL}=$ Pocket loop; $\mathrm{PA}=$ Plain arch; $\mathrm{PW}=\mathrm{Plain}$ whorl; RL=Radial loop; $\mathrm{TA}=$ Tented arch; UL=Ulnar loop. O-1= Observer 01; O-2= Observer 02. 
Table 3 Frequency of types of $A B O$ Rh blood groups among genders

\begin{tabular}{llll}
\hline Blood groups & Male $\mathrm{n}(\%)$ & Female $\mathrm{n}(\%)$ & Total $\mathrm{n}(\%)$ \\
\hline $\mathrm{A}+$ & $79(6.58)$ & $115(9.58)$ & $194(16.17)$ \\
$\mathrm{A}-$ & $10(0.83)$ & $16(1.33)$ & $26(2.17)$ \\
$\mathrm{B}+$ & $253(21.08)$ & $283(23.58)$ & $536(44.67)$ \\
$\mathrm{B}-$ & $26(2.17)$ & $27(2.25)$ & $53(4.42)$ \\
$\mathrm{AB}+$ & $49(4.08)$ & $58(4.83)$ & $107(8.92)$ \\
$\mathrm{AB}-$ & $15(1.25)$ & $13(1.08)$ & $28(2.33)$ \\
O+ & $90(7.50)$ & $127(10.58)$ & $217(18.08)$ \\
O- & $18(1.50)$ & $21(1.75)$ & $39(3.25)$ \\
\hline Total & $540(45)$ & $660(55)$ & $1200(100)$ \\
\hline
\end{tabular}

$\chi^{2}=4.14 ; p=0.764$.

Table 4 Correlation of types of ABO Rh blood groups with lip print patterns (in \%)

\begin{tabular}{llllllll}
\hline \multirow{2}{*}{ Blood groups } & \multicolumn{2}{l}{ Lip print patterns } & \multicolumn{1}{l}{ Total } \\
\cline { 2 - 6 } & $\mathrm{I}$ & $\mathrm{I}$ & $\mathrm{I}$ & $\mathrm{III}$ & $\mathrm{IV}$ & $\mathrm{V}$ & \\
\hline $\mathrm{A}+$ & 1.25 & 0.08 & 7.67 & 4.75 & 2.17 & 0.25 & 16.17 \\
$\mathrm{~A}-$ & 0.17 & 0.00 & 0.50 & 0.75 & 0.75 & 0.00 & 2.17 \\
$\mathrm{~B}+$ & 3.83 & 0.33 & 22.58 & 10.50 & 6.92 & 0.50 & 44.67 \\
$\mathrm{~B}-$ & 0.50 & 0.08 & 1.92 & 1.33 & 0.58 & 0.00 & 4.42 \\
$\mathrm{AB}+$ & 0.50 & 0.00 & 4.50 & 2.33 & 1.25 & 0.33 & 8.92 \\
$\mathrm{AB}-$ & 0.17 & 0.00 & 1.33 & 0.50 & 0.33 & 0.00 & 2.33 \\
$\mathrm{O}+$ & 1.17 & 0.08 & 9.33 & 4.83 & 2.58 & 0.08 & 18.08 \\
$\mathrm{O}-$ & 0.58 & 0.08 & 1.75 & 0.42 & 0.42 & 0.00 & 3.25 \\
\hline Total & 8.17 & 0.67 & 49.58 & 25.42 & 15.00 & 1.17 & 100.00 \\
\hline
\end{tabular}

I=Vertically running lip pattern; I'=Partial length; II=Branched; III=Intersected; $V=$ Reticular; $V=$ Undetermined.

The Type II lip pattern, followed by Type III, were the most frequently observed in all blood groups, except in A- blood group, where Type III and IV lip patterns were predominantly seen. The Type I' $(0.65 \%)$ followed by Type V (1.16\%), Type I (8.17\%), Type IV (15\%), Type III (25.41\%) and Type II (49.58\%) lip patterns were noted in ascending percentage in any of the blood groups (Table 4 ).

Also the UL fingerprint pattern (62.67\%) followed by the PW pattern (28.25\%), PL (4.41\%), PA (1.83\%), TA (1.58\%) DL (1.16\%) and RL $(0.08 \%)$ were noted most commonly in all the blood group patterns, while one subject with B blood group was noted with the RL fingerprint pattern. Also the primary fingerprint distribution among the Rh blood groups showed a high frequency of loops, a moderate number of Whorls, and few arches (Table 5).

The UL fingerprint pattern was most predominantly seen in all of the lip print patterns. Also the Type I' lip print pattern was noted least in all of the fingerprint patterns, followed by the Type $\mathrm{V}$ pattern (Table 6). 
Table 5 Correlation of types of ABO Rh blood groups with fingerprint patterns (in \%)

\begin{tabular}{lllllllll}
\hline \multirow{2}{*}{ Blood groups } & \multicolumn{2}{l}{ Fingerprint patterns } & & & & & Total \\
\cline { 2 - 7 } & $\mathrm{DL}$ & $\mathrm{PA}$ & $\mathrm{PL}$ & $\mathrm{PW}$ & $\mathrm{UL}$ & $\mathrm{TA}$ & $\mathrm{RL}$ & \\
\hline $\mathrm{A}+$ & 0.08 & 0.25 & 0.75 & 4.25 & 10.67 & 0.17 & 0.00 & 16.17 \\
$\mathrm{~A}-$ & 0.17 & 0.08 & 0.08 & 0.83 & 1.00 & 0.00 & 0.00 & 2.17 \\
$\mathrm{~B}+$ & 0.75 & 0.58 & 2.50 & 12.50 & 27.58 & 0.75 & 0.00 & 44.67 \\
$\mathrm{~B}-$ & 0.00 & 0.08 & 0.17 & 1.33 & 2.67 & 0.08 & 0.08 & 4.42 \\
$\mathrm{AB}+$ & 0.17 & 0.25 & 0.33 & 2.33 & 5.58 & 0.25 & 0.00 & 8.92 \\
$\mathrm{AB}-$ & 0.00 & 0.00 & 0.08 & 0.92 & 1.33 & 0.00 & 0.00 & 2.33 \\
$\mathrm{O}+$ & 0.00 & 0.50 & 0.42 & 5.25 & 11.58 & 0.33 & 0.00 & 18.08 \\
$\mathrm{O}-$ & 0.00 & 0.08 & 0.08 & 0.83 & 2.25 & 0.00 & 0.00 & 3.25 \\
\hline Total & 1.17 & 1.83 & 4.42 & 28.25 & 62.67 & 1.58 & 0.08 & 100.00 \\
\hline
\end{tabular}

$\mathrm{DL}=$ Double loop; $\mathrm{PL}=$ Pocket loop; $\mathrm{PA}=$ Plain arch; $\mathrm{PW}=$ Plain whorl; RL=Radial loop; $\mathrm{TA}=$ Tented arch; UL=Ulnar loop.

Table 6 Correlation of types of Lip prints with different fingerprint patterns (in \%)

\begin{tabular}{lllllllll}
\hline \multirow{2}{*}{ Types of lip print } & \multicolumn{2}{l}{ Fingerprint pattern } & & & & & \\
\cline { 2 - 7 } & DL & PL & PA & PW & RL & TA & UL & \\
\hline I & 0.00 & 0.25 & 0.00 & 2.33 & 0.00 & 0.33 & 5.25 & 8.17 \\
I' & 0.00 & 0.00 & 0.00 & 0.08 & 0.00 & 0.00 & 0.58 & 0.67 \\
II & 0.58 & 2.50 & 1.25 & 13.50 & 0.08 & 0.75 & 30.92 & 49.58 \\
III & 0.33 & 0.83 & 0.42 & 7.58 & 0.00 & 0.25 & 16.00 & 25.42 \\
IV & 0.25 & 0.83 & 0.17 & 4.33 & 0.00 & 0.25 & 9.17 & 15.00 \\
V & 0.00 & 0.00 & 0.00 & 0.42 & 0.00 & 0.00 & 0.75 & 1.17 \\
\hline Total & 1.17 & 4.42 & 1.83 & 28.25 & 0.08 & 1.58 & 62.67 & 100.00 \\
\hline
\end{tabular}

$\mathrm{I}=$ Vertically running lip pattern; I'=Partial length; II=Branched; III=Intersected; $V=$ Reticular; $V=$ Undetermined; Type I=A clear groove running vertically across the lip; Type I'=Partial length groove of type I; Type II=A branched groove; Type III=An intersected groove; Type IV=A reticular pattern; Type V=Undetermined; $\mathrm{DL}=$ Double loop; PL=Pocket loop; PA=Plain arch; PW=Plain whorl; RL=Radial loop; TA=Tented arch; UL=Ulnar loop.

\section{Discussion}

Forensic odontologists need knowledge that encompasses a number of disciplines, since dental records (21) can identify an individual or provide information needed by the authorities to establish neglect, fraud or abuse (22). Though not exclusive like an individual's DNA, fingerprints and lip prints and the $\mathrm{ABO}$ blood group system have the merits of being unique, permanent and are accepted evidence in a court of law (23). The correlation between variables can be used to calculate the strength between them, so the correlation of lip prints with $\mathrm{ABO}$ blood groups and fingerprints may be more useful in forensic science for the accurate identification of an individual than using individual parameter. Also it can narrow the search for an individual where there are no possible data referring to the identity of the subject.

Type II was the most predominant lip print pattern noticed (49.58\%) in both genders, while Type I' (incomplete vertical grove pattern) was noticed the least $(0.67 \%)$. The results were in accordance with previous studies $(6,15,24-26)$. In another study (27) Type I and Type I' patterns were found 
to be common in females while Type III and Type IV patterns were common in males, while the study by Naik et al. (18) showed that the Type IV pattern was the most prevalent in males and Type I/I' pattern was the most prevalent in females. These differences can be explained by the fact that lip print patterns are unique to different populations. Therefore, the variance can be explained by the ethnic, racial and geographical differences in the population studied (28), since in the present study only subjects from an Indo-Aryan ethnic race background were studied with their origins in the Northwestern region of India. Also, the different methods employed in the analysis of lip prints could be the reason for the disparity of the results.

The lip prints were recorded in closed relaxed position. The type of lip print was assessed in six areas and the pattern repeated the maximum number of times was considered to be the final lip print pattern, in accordance with Sivpathasundharam et al. (19), who stated that lip pattern recording depends on the way the lip muscles are relaxed to produce a particular pattern. The most widely accepted classification of lip print patterns, proposed by Suzuki and Tsuchihashi (4) in 1970, was followed. Moreover, it was found that it gave a clear description of nearly all the lip patterns commonly encountered and was easy to interpret. Its resemblance to the dental formula was also familiar to the forensic dentist (29). The 18-30 years age group was selected for the study as lips reach maturity in late adolescence (30). In the mid to late 30 's, although age changes begin to occur in the upper face, the lips retain their tonicity and do not show any agerelated changes (31). After 40 , due to the occurrence of wrinkles on the adjacent skin and thinning of lips, lip print patterns are affected (32).

The ulnar loop (UL) fingerprint pattern was the most predominantly noted in both genders $(39.50 \%$ in females and $23.25 \%$ in males) while the radial loop (RL) was least noted in both genders $(0.08 \%$ in females and none in males). The results were in agreement with previous studies (33-35). Cummins (36) in 1926 postulated that this was the result of physical and topographic growth forces, tension and pressure in the skin during early embryogenesis which determined the direction of the dermal ridge.

In India, $\mathrm{O}+$ is the most common blood group type (33) followed by $\mathrm{B}+$, but in our study $\mathrm{B}+$ was found to be most common in both genders $(21.08 \%$ males and $23.58 \%$ in females) while $\mathrm{A}-$ was the least noted blood group in males, and $\mathrm{AB}$ - in females. This might be due to different regional genetic backgrounds. Moreover, according to the various antigen-antibody reactions in the bloodstream, different individuals have specific blood groups. Similar results were also noted by Srilikha et al. (2), Verma et al. (6) and Patel et al. (37). Also the majority of subjects were $\mathrm{Rh}+(87.83 \%)$ while only $12.7 \%$ were $\mathrm{Rh}-$. These results were in accordance with previous studies $(14,33)$.

It was noted that the Type II lip print (branched) pattern was prominent among almost all blood group subjects, while the study conducted by Patel et al. (37) showed that in blood group A+ Type II was most prominent, and in blood group $\mathrm{B}+$ it was Type I, and in blood group $\mathrm{O}+$ it was noted to be Type II. The study conducted by Harsha et al. (38) showed that the reticular type (Type IV) of lip pattern was more prominent among subjects with $\mathrm{B}+$ blood group, and the vertical pattern (Type I) with $\mathrm{O}+$. Hence, from the data obtained and the conflicting results of previous studies, it is difficult to predict the blood group of an individual from the type of lip print pattern alone (39).

A significant correlation was observed between lip print patterns and ABO blood groups in the present study. This might be due to the fact that both lip prints and 
blood groups are genetically determined and developed during early foetal life (37). This contrasts with the studies conducted by Verma et al. (6), Furnari et al. (40) and Hunasgi et al. (41), due to the smaller study sample considered by past researchers, and moreover the present study reflected the most common whole upper and lower lips patterns (six quadrants considered), rather than partial lip area patterns. The UL fingerprint pattern was the most predominantly noted in both genders in all blood groups. Also, the three fingerprint patterns (Whorls, Arches and Loops) were seen more among $\mathrm{Rh}+$ subjects. Similar results were obtained by previous studies $(35,42)$.

A highly significant correlation was found between lip prints and fingerprints in both genders in the present study. This can be explained by the fact that the epidermal ridges of the fingers and palms, as well as the facial structures such as the lips, alveolus, teeth and palate, are formed from ectoderm during the same embryonic period (6-9 weeks) with a somewhat similar genetic background (43). Loop patterns of fingerprints were most predominantly seen in all the $\mathrm{ABO}$ blood groups while past studies $(44,45)$ found no or only a weak correlation between them. This again may be due to the small study samples of previous studies.

Nowadays the digital analyses of both lip prints and fingerprints are available (Adobe Photoshop, Veri Finger SDK, Precise Biometrics Biomatch ${ }^{\mathrm{TM}}$, etc) to avoid human error in manual analysis. A few studies have been conducted using digital analysis $(46,47)$, while others have been done using manual methods $(6,34)$, but both methods have showed no significant differences in their findings. Taking into consideration the large sample size, we performed the manual method with two observers. However more extensive and detailed research studies using digital analysis among different populations, considering racial and ethnic back- grounds, are required to establish a definite correlation between these variables. Also, the fingerprints of only the right hand were considered for the study, so the results could be fuller using fingerprints from both hands.

\section{Conclusion}

Both genders showed the Type II lip pattern and the ulnar loop (UL) fingerprint pattern to be the most predominantly recorded ectodermal patterns. The $\mathrm{B}+$ blood group was noted as most common in both genders. A highly significant correlation was found between lip prints, fingerprints and $\mathrm{ABO}$ blood groups in both genders in the IndoAryan (North-western India) ethnic background study population. Our regional, large sample sized study clearly reflects that the supplementary physical evidence (lip prints, fingerprints and $\mathrm{ABO}$ blood groups) can be assessed by simple and non-expensive techniques, and can be used as an additional tool in forensic investigations in the Sriganganagar population.

What is already known on this topic

With the ever increasing demands placed upon law enforcement to provide sufficient physical evidence linking a person to a crime, it makes sense to utilize any type of physical characteristic to identify suspects guilty of a particular offense. Personal identification plays an inevitable role in forensic investigations. Lip prints, fingerprints and $A B O$ blood groups are geno-typically determined and remain unchanged from birth until death.

\section{What this study adds}

Although extensive scientific research into the study of lip prints, fingerprints and $A B O$ blood groups is available the studies correlating and comparing all these three variables are minimal. However correlating these physical evidences at the crime scene may be used to substantiate facts in crimes where there is very little evidence. Moreover, regional data from the Sriganganagar district, Rajasthan (North-western India) on variables add to the existing data pool for forensic use.

Authors' contributions: Conception and design: PV and $\mathrm{HK}$; Acquisition, analysis and interpretation of data: HK, SP, and SSR; Drafting the article: HK; Revising it critically for important intellectual content: PV, 
HK, SSR and SP; Approved final version of the manuscript: PV, and SSR.

Conflict of interest: The authors declare that they have no conflict of interest.

\section{References}

1. Ranjan V, Sunil MK, Kumar R. Study of lip prints: A forensic study. J Indian Acad Oral Med Radiol. 2014;26(1):50-4.

2. Srilekha N, Anuradha A, Vijay Srinivas G, Sabitha Devi R. Correlation among Lip Print Pattern, Finger Print Pattern and ABO Blood Group. J Clin Diagn Res. 2014;8(3):49-51.

3. Remya S, Priyadarshini T, Umadethan B, Gopalan M, Jeyaseelan N. Cheiloscopy - A Study of Lip Prints for Personal Identification. IOSR Journal of Dental and Medical Sciences. 2016;15(2):101-3.

4. Suzuki K, Tsuchihashi Y. Personal identification by means of lip prints. J Forensic Med. 1970;17:527.

5. Mishra G. Lip prints. UP State Dent J. 2008;25:1822.

6. Verma P, Sachdeva SK, Verma KG, Saharan S, Sachdeva K. Correlation of Lip Prints with Gender, $\mathrm{ABO}$ Blood Groups and Intercommissural Distance. N Am J Med Sci. 2013;5(7):427-31.

7. Sharma P, Saxena S, Rathod V. Cheiloscopy: The Study of Lip Prints in Sex Determination. J Forensic Dent Sci. 2009;1:24-7.

8. Bindal U, Jethani SL, Mehrotra N, Rohatgi RK, Arora M, Sinha P. Lip prints as a method of identification in human being. J Anat Soc India. 2009;58(2):152-5.

9. Dolly A, Rodrigues C, Bankur R, Gopinathan PA, Sharma R, Doddamani A. Evaluation of efficacy of three different materials used in cheiloscopy -A comparative study. J Clin Diag Res. 2016;10(10):ZC67-71.

10. Santos M. Queiloscopy: A supplementary stomatological means of identification. Int Microform J Legal Med. 1967;1:2.

11. Mehta AA, Mehta AA. Palmar dermatoglyphis in $\mathrm{ABO}, \mathrm{RH}$ blood groups. Int J Biol Med Res. 2011;2(4):961-4.

12. Faulds H. Skin Furrows of the Hand. Nahest. 1880;22:605.

13. Henry ER. Classification and uses of finger prints. London: George Rutledge and Sons, Limited; 1900. p. 54.

14. Landsteiner K. On Agglutination on Normal Human Blood. Transfusion. 1961;1(1):5-8.
15. Metgud R, Kaur M, Naik S, Tak A, Patel S. Correlation between Lip Prints and Finger prints in $\mathrm{Gu}-$ jarati Population - A Forensic Study. J Adv Med Dent Scie Res. 2016;4(3):30-4.

16. Misra A, Misra D, Rai S, Dadu M, Khatri M, Mallick P. Crime solvers: A correlative study amongst 500 individuals. MAMC J Med Sci. 2017;3(2):79-86.

17. Nandan SRK, Bandaru BK, Santosh ABR, Thankappan P, Chundru NSV, Amudala R. A study on association and correlation of lip and finger print pattern analysis for gender identification. J NTR Univ Health Sci. 2015;4(3):176-81.

18. Naik SK, Prabhu A, Nargund R. Forensic odontology: cheiloscopy. Hong Kong Dent J. 2011;8:25-8.

19. Sivapathasundharam B, Praksh PA, Sivakumar G. Lipprints (Cheiloscopy). Indian J Dent Res. 2001;12(4):234-7.

20. Guyton AC, Hall JE. Text book in Medical Physiology. 11th ed. Pennsylvania: Elsevier Saunders; 2006. p. 451-4.

21. Melo M, Ata-Ali J. Accuracy of the estimation of dental age in comparison with chronological age in a Spanish sample of 2641 living subjects using the Demirjian and Nolla methods. Forensic Sci Int. 2017;270:276.e1-7.

22. Ata-Ali J, Ata Ali F. Forensic dentistry in human identification: A review of the literature. J Clin Exp Dent. 2014;6(2):e162-7.

23. Shah KK, Jayaraj G. Cheiloscopy for Sex Determination among Individuals Aged 17-25 Years. J Pharm Sci Res. 2015;7(9):731-5.

24. Verghese AJ, Somasekar M, Umesh BR. A study on lip print types among the people of Kerala. J Indian Acad Forensic Med. 2010;32(1):6-7.

25. Sandhu SV, Bansal H, Monga P, Bhandari R. Study of lip print pattern in a Punjabi population. J Forensic Dent Sci. 2012;4(1):24-8.

26. Mohammed A, Sharanesha RB, Virupakshappa D. Gender Determination Using Cheiloscopy in Pediatric Population. J Dent Med. 2015;14(1):60-3.

27. Vahanwala S, Nayak CD, Pagare SS. Study of lip prints as aid for sex determination. Medico Legal Update. 2005;5:93-8.

28. Abdel Aziz MH, Badr EI Dine FM, Saeed NM. Regression equations for sex determination using the lip print pattern among Egyptian and Malaysian adults. J Forensic Leg Med. 2016;44:103-10.

29. Devi A, Astekar M, Kumar V, Kaur P, Singh N, Sidhu GK. The study of inheritance analysis and evaluation of lip prints in individuals. J Forensic Dent Sci. 2015;7:49-53.

30. Genecov JS, Sinclair PM, Dechow PC. Development of the nose and soft tissue profile. Angle Orthod. 1990;60(3):191-8. 
31. Gordon RW. Age grouping to optimize augmentation success. Dent Today. 2010;29:128-31.

32. Kaul R, Padmashree SM, Shilpa PS, Sultana N, Bhat S. Cheiloscopic patterns in Indian population and their efficacy in sex determination: A randomized cross-sectional study. J Forensic Dent Sci. 2015;7:101-6.

33. Manoranjitham R, Arunkumar AKR, Gosai SR, Shalini R, Dandekar RH. Study of Palmar dermatoglyhics in $\mathrm{ABO}$ and $\mathrm{Rh}$ blood groups. Indian $\mathrm{J}$ Basic Appl Med Res. 2015;4(3):467-77.

34. Bansal N, Sheikh S, Bansal R, Pallagati S. Correlation between lip prints and finger prints in sex determination and pattern predominance in 5000 subjects. J Forensic Odontostomatol. 2013;31(1):8-14.

35. Raloti SK, Shah KA, Patel VC, Menat AK, Mori RN, Chaudhari NK. An Effort to Determine Blood Group and Gender from Pattern of Finger Prints. National J Community Med. 2013;4(1):158-60.

36. Cummins H. Palmar and Plantar Epidermal Ridge Configuration (Dermatoglyphics) in Europeans and Americans. Am J Phys Anthrop. 1926;9(4):471-502.

37. Patel R, Kempraj U, Patel H, Chavan S, Krishna M, Patel R. Assessment of Correlation of Lip Print with Gender and Blood Group among Dental Students of Visnagar, Gujarat, India. Int J Prevent Public Health Sci. 2015;1(1):14-8.

38. Harsha L, Gifrina J. Study on correlation of lip print, fingerprint and blood groups in a Tamilnadu based population. J Pham Sci Res. 2015;7(9):795-9.

39. Khanapure S, Suhas HG, Potdar S, Sam G, Sudeep $\mathrm{CB}$, Arjun MR. Association between Cheilo- scopic Patterns and ABO Blood Groups among South Indian Population. J Contemp Dent Pract. 2017;18(7):596-600.

40. Funari W, Janal MN. Cheiloscopy: Lip print interrater reliability. J Forensic Sci. 2017;62(3):782-5.

41. Hunasgi S, Koneru A, Gottipati H, Vanishree M, Surekha R, Manikya S. Comparison of lip prints, palatal rugae with blood groups in Karnataka and Kerala population. J Adv Clin Res Insights. 2014;3:83-8.

42. Desai B, Jaiswal R, Tiwari P, Kalyan JL. Study of Fingerprint Patterns in Relationship with Blood Group and Gender - a Statistical Review. Res J Forensic Sci. 2013;1(1):15-7.

43. Rekha VR, Sunil S, Rathy R. Heritability and Correlation of Lip Prints and Palmprints in South Kerala Population. Oral Maxillofac Pathol J 2015;6(1):544-9.

44. Mutalik VS, Menon A, Jayalakshmi N, Kamath A, Raghu AR. Utility of cheiloscopy, rugoscopy, and dactyloscopy for human identification in a defined cohort. J Forensic Dent Sci. 2013;5:2-6.

45. Nandan SR, Bandaru BK, Santosh AB, Thankappan P, Chundru NS, Amudala R. A study on association and correlation of lip and finger print pattern analysis for gender identification. J NTR Univ Health Sci. 2015;4(3):176-81.

46. Jatti D, Rastogi P. Digital analysis of lip prints for personnel identification: A cross-sectional study in South Indian population. J Indian Acad Forensic Med. 2015;37(3):289-93.

47. Prabhu RV, Dinkar A, Prabhu V. A study of lip patterns in Goan dental students - A digital approach. J Forensic Leg Med. 2012;19(7):390-5. 